\author{
Chantal Cardoso Cekiera e Sousa* \\ Krzysztof Butowski**
}

\title{
SOCIAL ASSISTANCE IN BRAZIL. UNTAPPED POTENTIAL OF CITIZEN PARTICIPATION?
}

\begin{abstract}
Brazil, the biggest country in South America creates the image of boundless land with unlimited richness of cultural diversity on a large scale. But its also creates big and very complicated social problems, which need to be solved. There is this huge number of citizens, who participate exclusively in poverty, hunger, misery, deprivation and violence.

This article shows that the history of the assistance was complicated and not linear, often inhibited its development due to certain historical events as a military dictatorship, which really slowed development. The Brazilian social policy was perceived as very inefficient and ineffective in fighting poverty. The article aims to trace the historical and current social assistance programs in Brazil.

There was practically no state-run social policy. Only in the era of industrialization workers' rights were implemented because of the fear of revolution and strikes. Social rights, as provision of housing or facilities for education and health care services were only applied to the formally employed - mostly male - urban, industrial proletariat. The biggest group of agricultural labourers (the overwhelming majority of the wage-dependent population as well as the majority of women) and unclassified workers were excluded from these benefits. Help was received by the group that the regime considered as dangerous. Social resistance against the dictatorial rule was growing.
\end{abstract}

* Law School, Federal University of Juiz de Fora, Brazil, e-mail: chantal_cekiera@yahoo.com.br

** Faculty of Humanities, Nicolaus Copernicus University in Toruń, Poland, e-mail: krzysiekbutowski@gmail.com 
It all started to change when the capital accumulation led to the creation of factories. In particular, the low human capital development was seen as a major cause of long-term poverty. New subjects like trade unions, active members of the middle class, the Catholic Church led to a public debate, the effect of which became a climate conducive to the adoption of the Constitution of 1988. Article 6 says that education, health, work, housing, leisure, security, social security, protection of motherhood and children, help for the poor and are social rights under the terms of this Constitution (Constitution of the Federative Republic of Brazil). This political agenda clearly pushed for the expansion and decentralization of public social spending. It has become a base for the social safety net.

The solution for the problem became Conditional Cash Transfer (CCT) programs. Bolsa-Escola, Comunidade Solidária Program, Alfabetização Solidária Program and finally Bolsa Familia aim to reduce poverty by making welfare programs conditional upon the receivers' actions. The assumption of purpose of these programs is to interrupt the inter-generational transmission of poverty. It can be also assumed that the aim of the Brazilian authorities was to achieve the effect of empowerment. The well-defined cashflows have resulted in the emergence of the phenomenon of empowerment, which has greatly raised the efficiency of social policy.

\section{Key words}

Brazil, social programs, social assistance, Bolsa Familia, citizens' participation

\section{Instead of introduction}

Brazil makes you think big. The biggest country in South America creates the image of boundless land with unlimited richness of cultural diversity on a large scale. But its also creates big and very complicated social problems, which need to be solved.

Despite the political instability, which is the result of the military government, influences of the conservative elites, who are supported by wealthy landowners, left wing politicians, the country goes through a rapid development, consisting in factories, roads and other infrastructure.

All this combined with a wealth of natural resources, creates almost unlimited possibilities of development, wealth, and power status, with possible $10 \%$ GDP.

But the economic growth hasn't gone hand in hand with decreasing poverty. Not all Brazilians could or might use all favours given by the development. There is this huge number of citizens, who participate exclusively in poverty, 
hunger, misery, deprivation and violence. From the time of independence, the gap between rich and poor people has been getting wider, and the amount of them has been growing alarmingly. They have formed a very distinct layers and social classes, which can't be beaten without help from the outside. The richest, representing $1 \%$ of the population obtains about $12 \%$ of income, while the poorest $50 \%$ brought in $10 \%$ of income. Such disparity places Brazil among the poor African countries (Brainard \& Martinez-Diaz, 2009, p. 2). About 30M people starved. Almost $40 \mathrm{M}$ citizens lived for less than 50 US $\$$ a month or less, and $1 / 3$ of society lived for 1 US \$ per day (Brainard \& Martinez-Diaz, 2009, p. 4).

The structure of the society reflects colonial times. The country could, but didn't get rid of characteristics of a colonial state, imposed by the Portuguese colonizers. Portuguese nobles were replaced by conservative landowners, cocoa and rubber owners. Later, these were replaced with industrialists. Between the mid 1960s and late 1970s, Brazil experienced the dictatorial regime with an average annual GDP growth, making anti-poverty policies a secondary priority (Pero \& Szerman, 2005). Basic social structure of a handful of privileged unchanged on the top, and huge numbers of poor societies as a basis. The high economic growth of the 1970s did not promote a sustainable reduction in poverty. The low economic growth of the 1980s pushed poverty back to levels of the mid 1970s.

To understand, how disproportionately the wealth was distributed, some statistics from time of turn of $20^{\text {th }}$ and $21^{\text {st }}$ century have to be checked.

The widespread belief that economic growth would eradicate poverty was weakened, highlighting the need to design effective anti-poverty policies. Poverty levels in Brazil have been higher than in other countries with similar development levels, despite the fact that public social spending has been proportionally higher than in other middle-income nations (Ferreira \& Camargo, 2000). The Brazilian social policy was perceived as very inefficient and ineffective in fighting poverty. There was a proposal of structuring the country's social assistance system.

The article aims to trace the historical and current social assistance programs in Brazil.

The authors' intention is also to draw more general conclusions. They may be used in the assessment of similar social programs of other countries.

The authors also wonder over how to raise the efficiency of operating aid schemes and try to identify the direction of future programs.

The main research methods used in the present study are: analysis of sources (both scientific and documentary studies), but also non-participatory observation. 


\section{Historical reasons of the current situation}

To understand why the country, dripping with oil, filled with coffee and sugar, is struggling with such deep social inequalities, we must go back to trace its history. This action will create a base for further research. Information obtained in this way will show what are the reasons for the current disparities and how today's social structure looks like. These actions are therefore essential to be able to answer the research question.

For more than 4 centuries, the Brazilian social system existed almost intact. A handful of white men, the elite exploited the human resources of natives, and when those ran out, the slaves were brought from Africa. Impossible to skip social classes, through clientelistic ties, Brazilian society was uncharged for ages. The country called today a multicultural, hundred years ago was turning off with the elites. Inequalities and social contrasts began to be seen as a problem scarcely at the beginning of the twentieth century.

Before the twentieth century, we can distinguish three main periods in the history of Brazil. The first was the period of colonialism, which lasted until 1822. At that time, the land of Brazil, as the overseas areas of operation, was a price for distinguished people from the kingdom of Portugal. The relations master-slave on sugar cane plantations were clearly defined by skin colour. White owners, managers, workers had their right to the land, in contrast to the black slaves, who had no rights to anything.

A little later in some areas of the country (mines) the owners, started to fear the possibility of revolt or denunciation to the king. The reason was the smuggling of gold. Information of that could give freedom. It began to develop a group of black residents who were not slaves and who began to deal with the craft as free people (Petelczyc \& Cichy, 2016, p. 136). Those communities created the roots of cities.

More important became harbour cities. The biggest at that time were Rio de Janeiro, Salvador da Bahia and Sao Luis de Maranhao (Petelczyc \& Cich, 2016, p. 127).

Second main period in the history of Brazil is a monarchy. During that time about $10 \%$ of people of Brazil lived in the cities; rest of them lived, worked and died mostly on plantation areas. Despite political changes, social structure remained intact, although the urban population began to augment the middle class. During that time the middle class formally abolished slavery in 1888 . Despite changes in the law, louder sounding liberal slogans, practical owners of 
the village remained conservative aristocrats, owners of vast areas (Petelczyc \& Cichy, 2016, p. 128).

Technological advances, the abolitionist movement and the advent of the Republic was the third main period in the history of the country. Meanwhile, the social structure is further dominated by the white elite, who owned the means of production. The results of political movements (including the Brazilian Republican Party of Sao Paulo from 1873) was that they become the main representatives of the interests of owners of coffee plantations (Petelczyc \& Cichy, 2016, p. 132).

The Constitution approved in 1891 introduced a presidential system and federalism, but still political life confined to the rule of the white elite. At the time, the importance of high-ranking soldiers called Coronels grew up. They subdued workers, peasants and group of holders of capital and goods, i.e. coffee growers from the region of Sao Paulo and the owners of "milk" from Mineas Gerais areas. Coronelism was based on the political monopoly of influential people, mostly close family and goods owners. Power and money again were bought in a small group of rich and powerful landowners and soldiers. Another generation of workers, mostly people with darker skin was condemned to hunger, poverty and lack of perspective of changing their situation (Petelczyc \& Cichy, 2016, p. 132).

Four hundred years of exploitation of indigenous people and the slave power, limiting access to land and education, led to huge social inequalities. Social right didn't exist. There was practically no state-run social policy. The needy were dependent on their benefactors and had to prove themselves thankful and loyal (Leubolt, 2014, p. 3). Relationships were based on personal dependencies between the slaves and their "masters" (Leubolt, 2014, p. 3). The elites were not interested in improving the fate of the poor, because poverty was conducive to effectively inhibit any desire to revolt and change. Workers' rights were implemented only because of the fear of revolution and strikes. According to the regime, European immigrants, inspired the idea of the revolution, were capable of threatening the regime itself. It mostly contributes to the selective improvement of living conditions of those groups that are especially likely to articulating political demands like, the Brazilian industrial proletariat, and could potentially become "dangerous" to the regime. State intervention "from above" thus prevents revolutionary movements "from below" (Leubolt, 2014, p. 3). Social rights, as provision of housing or facilities for education and healthcare services were only applied to the formally employed - mostly male - urban, industrial proletariat. The biggest group of agricultural labourers (the overwhelming majority of the 
wage-dependent population as well as the majority of women) and unclassified workers were excluded from these benefits. Help was received by the group that the regime considered as dangerous. The needs of scattered rural workers were still marginalized and ignored. The most important concessions for the industrial workforce were achieved by workers' rights starting in 1943 (Consolidação das Leis do Trabalho - CLT) (Leubolt, 2014, p. 6). The attempt to change the situation of farm workers in the form of granting them the land, which would lead to their inclusion into society, ended in 1964 with the coup. Again, middle class, great landowners and banking capital did not allow a change of the social structure. Social movements that opted for (re)distribution of goods were violently oppressed and social inequality did not decline. The clientelistic nature of distributional and social policy arrangements was upheld although they had been increasingly bureaucratized (Hall, 2008, pp. 799-822). During that period of time, marginalised people were still excluded from the agenda of social policies, but programs for the growing middle class were expanded.

Social resistance against the dictatorial rule was growing. The main reason for this was hyperinflation and the vast population of poor people. They changed the climate in the state to such an extent that in 1988 new constitution was passed (Hunter, Wendy-Power \& Timothy, 2007, pp. 1-30). The Constitution had very left-wing foundations and assumed inclusion in society of people so far excluded from state aid.

\section{Today's modern tools in the fight against poverty and social inequality}

As described previously, in the past, the Brazilian authorities were not concerned about the fate of unprivileged. As long as the poor, the needy and the oppressed did not threaten the people in power, the situation has not changed. It all started to change when the capital accumulation led to the creation of factories. They have become cluster of many employees. Their dissatisfaction, frustration, desperation could lead to conflicts and riots. Despite of the possibility they haven't been able to change their position. The size of the social differences remained at the same level. It had to be seen as a problem on a massive scale. In particular, the low human capital development was seen as a major cause of long-term poverty (Pero \& Szerman, 2005, p. 3).

The political situation, including the dominance of the landowners and industrial investors, still inhibited change. The coup in 1964, in which the army took power again, stopped reforms in social polities. This situation lasted until 
the eighties. Then the ideas concerning social polities in Brazil underwent major reforms, although social polities itself remained mostly unchanged. This had deep effects on the ideas concerning the country's social policy system, which had been in place since the 1930s. Corporatist and clientelist patterns guided their system, with access being restricted to those groups of the population with more bargaining force, notably, urban workers with formal jobs (Pero \& Szerman, 2005, p. 4). The liberalization of the economy in the 1970s, during the rule of the military allowed to show new actors on the stage of social policy. New subjects like trade unions, active members of the middle class, the Catholic Church led to a public debate, the effect of which became a climate conducive to the adoption of the Constitution of 1988. Article 6 says that education, health, work, housing, leisure, security, social security, protection of motherhood and children, help for the poor are social rights under the terms of this Constitution (Constitution of the Federative Republic of Brazil). The document deepened the ongoing decentralization process, strengthened the fiscal and administrative autonomy of sub-national governments. This political agenda clearly pushed for the expansion and decentralization of public social spending. It has become a base for the social safety net. Overall, social expenditures increased significantly throughout the decade, rising by $62 \%$ in a period over which the GDP and GDP per capita increased by $22.2 \%$ and $2.3 \%$, respectively (Pero \& Szerman, 2005, p. 5). The scientific reasons for this were the over-centralized structures and a lack of selectivity in social programs. Meanwhile, debates on proposals of minimum income programs evolved in the direction of conditional cash transfers (Pero \& Szerman, 2005, p. 6).

The beginning of the 90 s was a very difficult time for social policy. It was a period of struggle with hyperinflation, the time of drastic reductions in spending on social policy, the moment of implementation of the impeachment procedure of President Fernando Collor de Mello (Pero \& Szerman, 2005, p. 7). Nevertheless, it was also a time of introduction of the law on minimum income.

The solution for the problem became Conditional Cash Transfer (CCT) programs. They aim to reduce poverty by making welfare programs conditional upon the receivers' actions (Fiszbein \& Schady, 2009).

The purpose of these programs is to interrupt the inter-generational transmission of poverty. Other main reasons are: foster social inclusion by targeting the poor, focusing on children, delivering transfers to women, and changing social accountability relationships between beneficiaries, service providers and governments (De la Brière \& Laura, 2009). It can be assumed that the aim of the Brazilian authorities was to achieve the effect of empowerment. It involves 
in-premise - for activating a society that has the power of deciding about itself. This process is often associated with the fight for certain social rights. Here's how - interestingly - impulse was directed from the authorities. They offer the money. To receive them, people with need have to take some action, i.e. complete the application, submit the appropriate declarations.

One of the first most important tool for safety net programs have been Garantia de Renda Minima (PGRM) and the LOAS. They consist of payment of minimum wages to the poorest. The new approach of social security implied a direct money transfer to the disprivileged, including informal workers. They were meant to cut off the clientelism process, common in Brazil. In practice this form of support helped the poorest, but did not change the structural poverty. The transmission of poverty on the younger generations, who did not raise their level of education, because they had to work bringing income to support family, continued.

The program was modified with an emphasis on education of the younger generations and favoring attitudes encouraging the education of young people. Changes have lead to the reduction of child labor. This program was called Bolsa-Escola Program (BEP). Regardless of differences in political ruling party, the program assumed improving educational level as a main national goal in the middle term. First the program was implemented at the municipal level in the Federal District (DF) and in the city of Campinas. Families had to meet the following criteria:

a) income per capita had to be below a certain threshold: the majority used a threshold of between $1 / 2$ and $1 / 4$ of the minimum wage, while others used $\mathrm{R} \$ 35$ or $\mathrm{R} \$ 60$,

b) children must be in school age: the programs outside the state of São Paulo typically required children to be in the 7-14 age bracket. Municipalities within the state of São Paulo usually adopted broader brackets, including the $0-7$ age group,

c) families must met particular residency requirement: most municipalities limited access to the program by requiring a minimum time of residency. 43 out of the 58 programs listed by the World Bank (2001) required a minimum of two years of residency, while other programs required from 1-5 years,

d) mother must be a head of the family: 19 out of the 58 programs give priority to mother-headed families (de Janvry, Finan \& Sadoulet, 2006, p. 8). 
$30 \%$ of respondents, asked about the program responded that the program failed because of the poor planning and targeting. On the other hand, the BEP was well received by the elites, it also had a wide acceptance among the middle class. Additional studies estimating the impact of BEPs on educational indicators such as enrolment, attendance, drop-out rates and scholar achievement show that beneficiaries performed better than non-beneficiaries (de Janvry, Finan \& Sadoulet, 2006, p. 9). Results on child labor have not been as conclusive. The evidence demonstrates that the program was well targeted; that is, the beneficiaries' characteristics did match the selection criteria (Pero \& Szerman, 2005, p. 11).

Despite some differences, the program has been verified positively, and President Cardoso launched the National Bolsa-Escola Program (NBEP) in 2001, increasing significantly the amount of resources directed at the program. The NBEP was based on partnerships between the federal and municipal governments in a way to avoid shortcomings of over-centralized structures. In these partnerships, municipalities were responsible for the execution of the programs, while the federal government designed, coordinated and financed benefits (Pero \& Szerman, 2005, p. 15). Furthermore, scholarships were paid directly to the beneficiaries from the federal government, preferably to the mother, through the use of electronic cards. Finally, most of the spending was directed at poor municipalities within the 14 states with the lowest income (Pero \& Szerman, 2005 , p. 13). The amount of aid has grown to $\mathrm{R} \$ 1.5$ billion in 2001 . The program was well targeted. The second positive and innovative feature of this program was the universal criteria that guided the allocation of assistance. These two elements have led to more effective assistance focused on the real necessitous and better accomplished designed goals.

The above solutions were not the only ones. The period between 1980s and 1990s and the next decade were continuous attempts to trigger the phenomenon of empowerment, through successive, increasingly improved program delivery money. Here, example would be a program, launched in 1995, called Comunidade Solidária Program (CSP). It was created to help to fight hunger in the regions affected by drought. It also helped as a bridge between levels of governmental and civil organisations. Part of this project, Alfabetização Solidária Program, consisted of literacy classes taught by local University students. Innovative elements in the CSP were: federally structured policies; targeting the needs; close criteria; the geographical areas assisted by the program. Programs were operated by federal and municipal governments. Rules of participation 
were directed from federal to municipal governments. Program aimed to extend universal policies by targeting the poor (Pero \& Szerman, 2005, p. 18).

At that time, there were also in use federal projects to fight with child labour like PETI, launched in 1995 or Bolsa-Alimentação Program (BAP), helping pregnant or lactating women and/or with children below six years of age (Rawlings \& Rubio, 2003, p. 23).

A qualitative change in the social policy programs brought a merge of several programs into one under the name of Bolsa Familia. It was the integration of programs: Fome Zero Program (FZP) - reopened again after the election of Luiz Ignacio Lula da Silva for President in 2002, assuming food handouts and incentives/subsidies to local food production, Cartão-Alimentação (food support), Auxílio Gás (a bi-monthly cash transfer of $\mathrm{R} \$ 15$ to families with a per capita income less than half of the minimum wage. The idea was to compensate those families for the elimination of a subsidy on cooking gas).

Situation meant the creation of a new Ministry - Ministry for Social Development and Confronting Hunger (Ministério do Desenvolvimento Social e Combate à Fome) which merger reduced administrative costs and also eased bureaucratic complexity for both the families involved and the administration of the program. The Bolsa Família Program (The BFP) was created in January 2004 to integrate management responsibilities of four federal conditional cash transfer programs and the register of the targeted population in the Cadastro Único (Rawlings \& Rubio, 2003, p. 20).

Main features of the program:

- Assistance to the family and not to its members separately,

- Conditions to be fulfilled by the families and the government in the areas of health, education and social assistance,

- Direct payment to the family, without any intermediaries,

- Benefit paid preferably to the woman,

- Autonomy of the family to use the financial resource,

- Assistance to the poor and extremely poor families,

- Families remain in the program while their income is lower than the eligibility criterium: there is no deadline for permanence in the program,

- Shared management between government levels (federal vs local),

- Participation of the society,

- National coverage (based on an estimate of poor families) (Bolsa Familia Program).

Program was dedicated to: families with monthly per capita income between $\mathrm{R} \$ 60,01$ and $\mathrm{R} \$ 120,00$ with children between 0 and 17 years old and families 
with monthly per capita income of up to $\mathrm{R} \$ 60,00$, regardless of the family (Bolsa Familia Program). To receive the money from this program families are required to respect the following conditions:

- Enrolment and regular school attendance for children aged 6-15 years,

- Regular vaccination for children aged 0-6 years,

- Pre-natal visits for pregnant women (Bolsa Familia Program).

About 12 million Brazilian families receive funds from Bolsa Família. It has been described as "the largest programme of its kind in the world" (Duffy, 2010). According to research promoted by some universities and the Brazilian Institute of Geography and Statistics (IBGE), the program has clearly contributed to Brazil's recent improvements in its fight against poverty. A study by the UNDP's International Policy Centre for Inclusive Growth found that over 80\% of the Bolsa Familia benefits go to families in poverty (making under half the minimum wage per capita), thus most of the benefits go to the poor, which have given about 44 million beneficiaries (Bolsa Familia Program). The World Bank, which provided a loan to assist the Brazilian government in managing the Bolsa Família Program, declares that "Although the program is relatively young, some results are already apparent: (...) contributions to improved education outcomes, and impacts on children's growth, food consumption, and diet quality" (Bolsa Familia Program). Bolsa Familia is also found to have been responsible for about $20 \%$ of the drop in inequality.

Nevertheless, also the Bolsa Familia program is not free from defects. To a large extent it affects similar risks as the previous programs. Bolsa Família is formidable, but the benefits are still too low and there are eligible families that are not in the program. Civil servants' social security is inordinately expensive and runs huge annual deficits. Educational attainment is still too low and the overall quality of public schools is substandard. Some policies that could do a lot to reduce poverty and inequality have been pretty much set aside (i.e. land reform).

The way to upgrade and improve the efficiency of BFP could be through the concept of empowerment. It is the process of engaging people in decisions, relating to the organization and enabling them to take responsibility for their actions, which translates into cost consciousness, a sense of belonging, increased productivity and improved relationships through the feeling that they have real decision-making power. This leads to the fact that people approach tasks as "managers" with greater responsibility and commitment (Blanchard, 2007).

The doctrine of social development/ decision making by the public concept of empowerment-has began in the 1970s. Peter Berger and Richard Neuhaus 
understand empowerment as a way to improve social services through the introduction or inclusion in the process of distribution of state support of intermediaries. Among others, it could be family, church and various associations (Berger \& Neuhaus, 1977).

Empowerment as practice is about shaping subjectivities. Main objective of empowerment is to encourage conformity toward new policy innovations, whether in the western countries or in postcolonial regions of the world (Harrison, 2007).

This method was known as social work with the oppressed people of AfroAmerican descent, where the admission of the group of beneficiaries (social assistance) to the process of resource allocation would increase their self-esteem, as well as (their) ability to solve everyday life problems (Solomon, 1976).

Brazilian CCTs haven't stressed enough on sectors like microcredit and job training (Pero \& Szerman, 2005, p. 20). The support has been mainly focused on basic problems like hunger, access to education and improving access the health system. There hasn't been enough thinking of work against unemployment. There is lack of activity in stimulating entrepreneurship mechanisms such as microcredit, or retraining of the labor market.

CCT programs have not been properly monitored by non-governmental institutions. Some elements of support and investment in the education of the young generation brings results after many years. Due to lack of proper monitoring, it can not be told whether the money was spent in the best way.

We could say that the concept of direct payments of funds is effective, but only to a certain point. No doubt they are an apt way of social assistance, aimed at elimination of existential threats to humans, such as hunger, lack of elementary means of livelihood. As practice shows, such action is not an appropriate technique to motivate people to radical structural change of life. It turns out that the beneficiaries of such assistance rarely decide to resign in favor of work. Therefore, in the long term, BFP and other CCT programs may even, paradoxically, lead to leaving large sections of society inactive, not interested in cooperation with local authorities or community development opportunities to shape their own destiny. This would then be the opposite effect of empowerment ${ }^{1}$. Therefore, consider a situation in which part of the funds would be spent on creating the conditions for independent activity that would satisfy the needs e.g. the creation of a network of nurseries, kindergartens, community centers, where children

1 In the long run the public becomes accustomed to this form of financing of its life activity. People begin to treat it as a kind of steady income. 
could stay to enable their parents a job search. Another idea could be to use these funds for development of local communities, involving cooperation between public authorities and citizens - emphasis on the responsibility for own actions, spending money and liability connected with it is the result of extension of this concept. This phenomenon could build confidence, skills and powers of local communities to shape and influence what public bodies do "with them, or for them" (Communities and Local Government, p. 12). New integrated programs instead of ad hoc help for the unprivileged, could give them some power in order to decide about their issues. Such action builds creativity, accountability, predictability, but also requires a certain knowledge, management skills.

Having all this in mind, one can say that the end of the widespread belief that economic growth would generate a sustainable poverty reduction led policy makers to concentrate more efforts on the design of anti-poverty policies. Turbulences in the economy, spikes of inflation, the collapse of the military regime led to a change of approach in many areas of life, including a new perception of poverty.

The macroeconomic shocks that the country underwent in the 1980s reinforced this notion, leading to the idea of social safety nets to protect the most vulnerable from economic fluctuations.

What we cannot argue with is that since 1988 the programs pulled up millions of Brazilian citizens from extreme poverty, integrated them into society and provided them with basic goods of modern civilization, such as access to basic infrastructure and services ${ }^{2}$.

This kind of help system in Brazil has evolved from simple programs covering one region, to complex multi-dimensional programs consisting of several "sub-programs". The effect of such actions is more complex assistance, covering more areas of life (hunger, social exclusion), more groups is involved to social life (children, elderly). It was possible because of the data collected earlier on simpler programs, directing a stream of aid to the relevant groups in need.

CCT programs, as the name suggests is a support tool involving the transfer of money to groups in need. The consequence of such aid is the increase in the

2 Moreover, the introduction of a minimum wage mechanisms and facilitating access to health services has improved the condition of older people. Further poverty and inequality reduction was possible by making more effective social policies and thanks to consumer-led economic boom. The idea of involving the promotion of education of the youth was revolutionary. It has interrupted the transmission of poverty to the younger generation. School is the possibility of a different life and work than models and procedures that children learn at home. 
purchasing power of household budgets which translates into a greater quantity and quality of the products they buy. Usually, it is mainly food (Rutter, 2012).

But, trying to be objective, it is hard not to point out that these programs have in their structure certain, potential risks. And so, at the very start, it has to be said, as mentioned at the beginning, Brazil makes you think big. Therefore, one of the risk is the scale of assistance. Number of problems to solve for such a large area with correspondingly low budget causes difficulties in choosing who and how to help at first. Therefore, in the context of many years of activities the most acute problems chosen the fight against poverty, support education, nutrition and health.

Another problem is that, due to the political shifts, elections, changes of government, reforms, but also natural disasters, it is not possible to eliminate the threat involving the discontinuation of programs, delayed payments, and changing the criteria for selection of people in need. Another, quite a significant threat is the financial crisis. Decline in demand for exported goods leads to a decrease of income from their sale. This can endanger the funding of CCT programs (Fizbein \& Shaby, 2009, p. 125). This is not a hypothetical situation. Due to the export of unprocessed raw materials - minerals - representing a substantial national income, Brazil has become a victim of falling prices. This heavily influenced the country's politics and partly led to a political succession, and consequently to changing the President.

Exclusion is another danger for CCT effectiveness. Because of the lack of access or its limitation, many in need were not covered by aid. This may be due to geographical location, distance, lack of appropriate infrastructure, i.e. roads, transport, lack of media. The costs of programs may be higher than their effects, hence the threat involving the exclusion of people from programs, despite their formal qualification to a particular program (Fizbein \& Shaby, 2009, p. 127).

Lack of trust due to incorrect information campaign is another threat. Without proper preparation on how to inform what is the purpose of the project, the project may fail. It is therefore important that the recipients know what they can count on, which cases the project helps in. Nobody wants to be the subject of a political game, thus doubts whether the aid is politicized or not must be clearly addressed.

Our biggest worry is that social policy doesn't involve enough tools that support human capital. Unstable domestic politics, detected corruption scandals, the process of impeachment don't make social policy more effective in work against poverty. Redistributing human capital is essential to ensure that the poor can benefit from, and contribute to, economic growth. Without the change 
in approach, the effectiveness of the program will not increase and the results will not be permanent. There is still plenty of room for improvement (Fizbein \& Shaby, 2009, p. 21).

\section{Instead of conclusions}

This article shows that the history of the assistance was complicated and not linear, often inhibited its development due to certain historical events such as a military dictatorship, which really slowed development. Eventually other systems failed, leaving behind a growing crowd of the hungry, the helpless citizens, created a society dangerous suburbs/favelas, violence and social inequality. Years of neglect have cost Brazil billions of Reals to reduce some of the biggest social inequalities. When basic needs are met, assistance tools have been modified and integrated in order to work at higher levels of the pyramid of needs. The authors estimate that the qualitative changes of tools have become a necessity. Other programs must fight famine and other - intergenerational transmission of poverty. According to the authors, the next action of rulers should be the inclusion of the same need for outreach activities. Their presence, commitment and responsibility for decisions will create a modern society, sensitive to the needs of the lower strata of society and hamper the temptations of power.

Such proposals could be applied also in the fight against poverty in countries such as Poland, where poverty has other causes.

This would require, however, more and deeper research. The question is whether the rulers and society in Brazil are ready for such a change and the transfer of responsibility for their own actions?

\section{REFERENCES}

Bauman, Z. (2009). Konsumowanie życia [Consuming Life]. Wydawnictwo Uniwersytetu Jagielońskiego.

Berger, P., \& Neuhaus, R. (1977). To Empower People: The Role of Mediating Structures in Public Policy, Studies in political and social processes. Washington. Aei Press; Ex-seminary Library edition.

Blanchard, K. (2007). Przywództwo wyższego stopnia [Leadership of higher degree]. Warszawa: PWN.

Bolsa Familia Program, Slideshow. Retrieved from http://www.ipc-undp.org/doc_africa_brazil/6.SENARC_Overview_PBF.pdf. 
Brainard, L., \& Martinez-Diaz, L. (2009). Brazil as an economic power? Understanding Brazil's changing role in the global economy. Washington D.C.: Bookings Institution Press.

Brazil's Bolsa Familia Program Celebrates Progress in Lifting Families out of Poverty, The World Bank, News and Broadcast. Retrieved from http://web.worldbank.org/ WBSITE/EXTERNAL/NEWS/0,,contentMDK:20702063 pagePK:64257043 piPK: 437376 theSitePK:4607,00.html.

Communities and Local Government (2007). An Action Plan for Community Empowerment: Building on Success. Wetherby.

Damgaard, Ch., Gini Coefficient. Retrieved from http://mathworld.wolfram.com/GiniCoefficient.html.

de Janvry A. \& Finan, F., Sadoulet, E. (2006). Evaluating Brazil's Bolsa Escola Program: Impact on Schooling and Municipal Roles, University of California at Berkeley. Retrieved from http://are.berkeley.edu/ esadoulet/papers/BolsaEscolaReport6-6.pdf.

De la Brière, B. \& Laura, R. B. (2006). Examining Conditional Cash Transfer Programs: A Role for Increased Social Inclusion? Social Safety Net Primer Papers. The World Bank. Retrieved from http://siteresources.worldbank.org/SOCIALPROTECTION/ Resources/SP-Discussion-papers/Safety-Nets-DP/0603.pdf.

Duffy, G., Family friendly: Brazil's scheme to tackle poverty, BBC. Retrieved from http:// www.bbc.com/news/10122754.

Fiszbein, A., \& Schady. Conditional Cash Transfers: Reducing Present and Future Poverty. Policy Research Report World Bank, Retrieved from http://web.worldbank.org/ WBSITE/EXTERNAL/TOPICS/EXTSOCIALPROTECTION/EXTSAFETYNETS ANDTRANSFERS/0,,contentMDK:22060179 pagePK:148956 piPK:216618 theSit ePK:282761 isCURL:Y,00.htm.

Fizbein, A., \& Shaby. N. (2009). Conditional Cash Transfers: Reducing Present and Future Poverty. The World Bank.

GINI Index, Development Research, Word Bank. Retrieved from http://data.worldbank. org/indicator/SI.POV.GINI? end=2013\&locations=BR-PL\&order $=$ wbapi_data_ value_2011+wbapi_data_value+wbapi_data_value-last\&sort=asc\&start=1981\&view =chart, 1.9.16.

Hall, A. (2008). Brazil's Bolsa Familia: a double-edged sword? Development and change, 39(5). Retrieved from https://core.ac.uk/download/pdf/209941.pdf, 1.9.16.

Harrison, G. (2007). Empowerment, Encyclopedia of Governance. Berkeley: University of California.

Leubolt, B. (2014). Social policies and redistribution in Brazil. Working Paper, 26. Retrieved from http://www.global-labour-university.org.

Pero, V., \& Szerman, D. (2005). The New Generation of Social Programs in Brazil, Seminatios, Insituto de economia, Universidade Federal do Rio de Janeiro. Retrieved from http://www.ie.ufrj.br/eventos/pdfs/seminarios/pesquisa/the_new_generation_of_social_programs_in_brazil.pdf. 
Petelczyc, J., \& Cichy, M. (2016). Brazil, the land of future? Warszawa: Instytut Wydawniczy Książka Polska.

Poverty headcount ratio at national poverty lines (\% of population), World Bank, Global Poverty Working Group. Retrieved from http://data.worldbank.org/indicator/SI.POV.NAHC?end=2013\&locations=PL-BR\&start=2000.

Rawlings, L., \& Rubio, G. (2003). Evaluating the Impact of CCT Programs: Lessons from Latin America. World Bank Working Paper Research Policy, 3119, p. 23.

Rutter, J. (2012). Making the case for rigorous, evidence-based policymaking. The Guardian. Retrieved from http://www.povertyactionlab.org/evaluation/experimentincentive-based-welfare-impact-progesa-health-mexico.

Solomon, B. (1976). Black Empowerment: Social work in Oppressed Communities. New York.

Wolf, N. (2008). Mit piękności [Beauty Myth]. In M. Szpakowska (ed.), Antropologia ciała. Zagadnienia i wybór tekstów [Anthropology of the Body. Issues and Choice of Texas] (45). Warszawa. Wydawnictwo Uniwersytetu Warszawskiego. 